2014

\title{
The Incurable Constitutional Itch: Transnational Private Regulatory Governance and the Woes of Legitimacy
}

Peer C. Zumbansen

Osgoode Hall Law School of York University, pzumbansen@osgoode.yorku.ca

Follow this and additional works at: https://digitalcommons.osgoode.yorku.ca/olsrps

\section{Recommended Citation}

Zumbansen, Peer C., "The Incurable Constitutional Itch: Transnational Private Regulatory Governance and the Woes of Legitimacy" (2014). Osgoode Legal Studies Research Paper Series. 56.

https://digitalcommons.osgoode.yorku.ca/olsrps/56 


\section{OSGOODE}

OSGOODE HALL LAW SCHOOL

YOR K U N I VERSITY

\section{OSGOODE HALL LAW SCHOOL}

LEGAL STUDIES RESEARCH PAPER SERIES

Research Paper No. 18/2014

Vol. 10, No. 6 (2014)

The Incurable Constitutional Itch: Transnational Private Regulatory Governance and the Woes of Legitimacy

Peer Zumbansen

Editors:

Peer Zumbansen (Osgoode Hall Law School, Toronto; Canada Research Chair in Transnational Economic Governance and Legal Theory - Editor in Chief)

Stephen Ji (Osgoode Hall Law School, Toronto - Production Editor) 


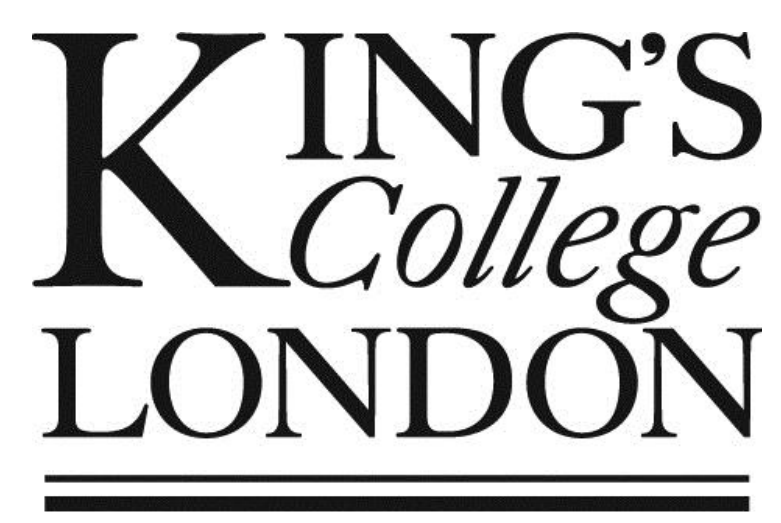

\title{
The Incurable Constitutional Itch: Transnational Private Regulatory \\ Governance and the Woes of Legitimacy
}

\section{Peer C Zumbansen}

\author{
The Dickson Poon School of Law \\ Somerset House East Wing \\ Strand Campus \\ The Strand, London \\ WC2R 2LS
}


Osgoode Legal Studies Research Paper No. 18/2014

Vol. 10, No. 6 (2014)

\title{
The Incurable Constitutional Itch: Transnational Private Regulatory Governance and the Woes of Legitimacy
}

Forthcoming in: Michael Helfand (ed.), The Challenges of Global and Local Legal Pluralism: Mediating State and Non-State Law, Cambridge University Press, 2014.

Peer Zumbansen

\begin{abstract}
:
Transnational private regulatory governance in a host of areas from food and product safety, aviation security, accounting, corporate and labor standards, as well as forestry and marine stewardship has long attracted the attention of those with concern for the public interest. The chapter recognizes these concerns, which are usually expressed in terms of a wide-ranging legitimacy deficit of private governance regimes. At the same time, I contend that there is no easy fix in response to regulatory developments that have their origin in nation-state transformation and in a functionally differentiated proliferation of global societal activity. I provide a brief account of what is here called the 'Global Governance condition' and of the particular challenges emanating therefrom for the development of legal agency. I then engage with law's potential to resituate itself in a global context against the background of competing accounts of functionalism and normativism. Thereafter follows a discussion of the particular role played by private law in navigating public and private interests and of the (futile?) aspirations for a political critique. The next section contextualizes the public-private law dynamics against the background of a high degree of functional and sectorial specialization which characterizes transnationalization processes and significantly challenges any effort of designing overarching and inclusive models or concepts of post-national justice. The concluding section interrogates the prospects of an interdisciplinary and normative engagement with the pressing political regulatory challenges that arise from law's transnationalization.
\end{abstract}

\section{Keywords:}

Transnational Private Regulatory Governance; regulatory capitalism; private governance; legitimacy; rule of law; critical theory; systems theory; methodological transnationalism.

\author{
Author(s): \\ Peer Zumbansen \\ Professor of Law \& Canada Research Chair \\ Osgoode Hall Law School, Canada \\ Spring 2014, Visiting Professor, Yale Law School \\ E: Pzumbansen@osgoode.yorku.ca
}




\title{
The Incurable Constitutional Itch: Transnational Private Regulatory Governance and the Woes of Legitimacy*
}

\author{
Peer Zumbansen ${ }^{* *}$
}

\section{A. Introduction}

As transnational commercial lawyers have long known, border crossing, globe-spanning economic activities and business practices prompt legal responses that extend the public-private interplay and legal pluralism of the nation-state to - literally - unchartered territory. ${ }^{1}$ In the transnational space of exchange and trade of the modern age, law evolves through the interplay of "transnational lift-off and juridical touchdown", constantly re-drawing the boundaries between private agency and public authority. As for lawyers, these contemplate whether or to what degree segments of this transnational regulatory regime - the mysterious and mesmerizing lex mercatoria - should properly be called law. ${ }^{3}$ And while from the perspective of sociology

\footnotetext{
*This chapter is part of an ongoing research project investigating the tensions between the global proliferation of private regulatory arrangements and a growing concern regarding the protection of public interests in this constellation. The following pages are based on my presentation at the American Society of International Law ASIL - International Legal Theory Interest Group Symposium, 'The Rise of Non-State Law', Tillar House, Washington, D.C., in May 2013. I am grateful to Professor Michael Helfand for the invitation and for the organization of a very stimulating and diverse symposium. It built on earlier presentations at Indiana University, Maurer School of Law, at Osgoode Hall Law School in Toronto, the European University Institute, Florence, at McGill University, Faculty of Law and the Law School of Graduate Studies, Nagoya University, Japan. I am indebted to Yuki Asano, Larry Backer, Paul Berman, Takeshi Fujitani, Michael Helfand, Sally Merry, Christiana Ochoa, Alessandro Somma, Colin Scott and Dai Yokomizo for generous comments and feedback. Finally, I am grateful for the permission to draw in very small parts on an essay on 'The Ins and Outs of Transnational Private Regulatory Governance', published in the German Law Journal in December 2012.

${ }^{* *}$ Professor of Law and Canada Research Chair, Osgoode Hall Law School, Toronto. Founding Director, Critical Research Laboratory in Law \& Society. 2013-2014 Senior Research Scholar, University of Michigan, School of Law, and Visiting Professor, Yale Law School. Email: PZumbansen@osgoode.yorku.ca /

peer.zumbansen@yale.edu
}

${ }^{1}$ C. M. Schmitthoff, 'International Business Law: A New Law Merchant', (1961) 2 Current Law and Social Problems 129-153; R. Goode, 'Usage and Its Reception in Transnational Commercial Law', (1997) 46 International and Comparative Law Quarterly 1-36; R. Cranston, 'Theorizing Transnational Commercial Law', (2007) 42 Texas International Law Journal 597-617.

${ }^{2}$ R. Wai, 'Transnational Liftoff and Juridical Touchdown: The Regulatory Function of Private International Law in an Era of Globalization', (2002) 40 Columbia Journal of Transnational Law 209-274.

${ }^{3}$ B. Goldman, 'Frontières du droit et 'lex mercatoria", (1964) 13 Archives de la Philosophie de Droit 177-192; K.-P. Berger, 'Transnational Commercial Law in the Age of Globalization', (2001) 42 Centro di studi e ricerche di diritto comparato e straniero $1-29$. 
and geography, the evolving landscape challenges conceptions of location and boundaries ${ }^{4}$, for political science the focus must be on the element of authority. ${ }^{5}$ In other words, the urgent political question of transnational governance regards control, the emblem of power. As the sites and trajectories of transnational governance continue to span more and more regulatory areas, the combined question of 'who's in charge and to whose benefit?' has to move into the center of an interdisciplinary engagement. Law's history of interdisciplinarity situates it well for a productive contribution to this enterprise, which is one that must go beyond lipservice to the need of thinking about law and globalization from an interdisciplinary perspective; crucially, it is the normative challenge of transnational governance which prompts a reflection on its stakes, interests and aspirations. Law's engagement with the spatialization of transnational governance regimes under post-national ${ }^{6}$ conditions must address the normative challenge, political philosophers and political scientists have long been addressing. ${ }^{7}$ The question raised in this chapter is how law and, more specifically, developments in private law theory address the normative challenges of transnational private regulatory governance. The larger issue behind this question concerns private law's contribution to a legal theory of global governance, with the contention - from a historical perspective - that private law has always played a central in social regulation. ${ }^{8}$ The chapter will provide a brief account of what shall here be referred to as 'the Global Governance condition' and of the particular challenges emanating therefrom for the development of legal agency (B) and for law's imagination against the background of competing accounts of functionalism and normativism (C). Thereafter follows a discussion of the particular

\footnotetext{
${ }^{4}$ S. Sassen, 'The Places and Spaces of the Global: An Expanded Analytic Terrain', in D. Held and A. McGrew (eds), Globalization Theory. Approaches and Controversies (Polity, 2007), 79-105; D. Harvey, 'The Sociological and Geographical Imaginations', (2005) International Journal of Politics, Culture and Society 211-256.

${ }^{5}$ See now the brillant analysis by Nicole Roughan, Authorities (2012), as well as by L. C. Backer, 'Governance without Government - An Overview', in G. Handl, J. Zekoll and P. Zumbansen (eds), Beyond Territoriality. Transnational Legal Authority in an Age of Globalization (Brill, 2012),

${ }^{6}$ D. Held, Democracy and the Global Order (Polity Press, 1995); J. Habermas, The Postnational Constellation (MIT Press, 2001).

${ }^{7}$ See eg A. C. Cutler, 'Global Capitalism and Liberal Myths: Dispute Settlement in Private International Trade Relations', (1995) 24 Millennium: Journal of International Studies 377-397, D. Levi-Faur, 'The Global Diffusion of Regulatory Capitalism', (2005) 598 The Annals of The American Academy of Political and Social Science 12-29, J. G. Ruggie, 'Reconstituting the Global Public Domain - Issues, Actors, and Practices', (2004) 10 European Journal of International Relations 499-531, and the contributions to J. L. Dunoff/J. P. Trachtman (eds), Ruling the World? 'Constitutionalism, International Law, and Global Governance (Cambridge University Press, 2009).

${ }^{8}$ See eg M. Weber, On Law in Economy and Society (transl. from the German Wirtschaft und Gesellschaft, 2nd ed., 1925, by E.Shils and M.Rheinstein, edited/annotated by M.Rheinstein) (Simon Schuster, 1967), and K. Renner, The Institutions of Private Law and their social functions (orig. German 1929) (Routledge and Kegan Paul, 1949).
} 
role played by private law in this context in navigating public and private interests (D) and the (futile?) aspirations for a political critique (E), while the next section contextualizes the publicprivate law dynamics studied earlier against the background of the high degrees of functional and sectorial specialization that characterize transnationalization processes and significant challenges these pose for any effort of designing overarching and inclusive models or concepts of postnational justice $(\mathrm{F})$. The concluding section interrogates the prospects of an interdisciplinary and normative engagement with the pressing political regulatory challenges that arise from law's transnationalization $(\mathrm{G})$.

\section{B. The Global Governance Condition: Questioning the Standard Account}

As in Shakespeare's plays, it is only when a third party arrives, knocks on the door and enters the scene that the actors on stage are bound to see more clearly what it is they are in fact struggling with. Public law's catch-up game with transnational private regulatory governance over the past decades is illustrative in that regard. ${ }^{9}$ Whether the focus is on food safety ${ }^{10}$ or intellectual property rights attached to foods ${ }^{11}$, on accounting standards $^{12}$, on forestry ${ }^{13}$ or marine stewardship ${ }^{14}$, on the taming of multinational corporations ${ }^{15}$ or the promotion of human rights

\footnotetext{
${ }^{9}$ See eg S. Bernstein/B. Cashore, 'Can non-state global governance be legitimate? An analytical framework', (2007) 1 Regulation \& Governance 347-371, and A. Bogdandy/P. Dann/M. Goldmann, 'Developing the Publicness of Public International Law', (2008) 9 German Law Journal 1375-1400, as well as the comprehensive case studies included in the same issue.

${ }^{10}$ D. K. Casey/J. S. Lawless, 'The parable of the poisoned pork: Network governance and the 2008 Irish pork dioxin contamination', (2011) 5 Regulation and Governance 333-349; D. N. Scott, 'Nature/Culture Clash: The Transnational Trade in GMOs', (2005) Global Law Working Paper Series http://www.nyulawglobal.org/GLWP_0605.htm.

${ }^{11}$ M. J. Rippon, 'Traditional Foods, Territorial Boundaries and the TRIPS Agreement: The Case of the Melton Brow Pork Pie', (2013) 16 The Journal of World Intellectual Property 262-301.

${ }^{12}$ B. Grossfeld, 'Comparative Corporate Governance: Generally Accepted Accounting Principles v. International Accounting Standards', (2003) 28 N.C. J. Int'l L. \& Com. Reg. 847-877; Y. Biondi/T. Suzuki, 'Socio-Economic Impacts of International Accounting Standards: An Introduction', (2007) 5 Socio-Economic Review 585-602.

${ }^{13}$ P. Pattberg, 'What Role for Private Rule-Making in Global Environmental Governance? Analysing the Forest Stewardship Council', (2005) 5 International Environmental Agreements 175-189; E. Meidinger, 'The Administrative Law of Global Private-Public Regulation: the Case of Forestry', (2006) 17 European Journal of International Law 47-87.

${ }^{14}$ S. Ponte, 'The Marine Stewardship Council (MSC) and the Making of a Market for 'Sustainable Fish', (2012) 12 Journal of Agrarian Change 300-315. See also the main site for the Marine Stewardship Council at: http://www.msc.org/.

${ }^{15}$ L. Bennie/P. Bernhagen/N. J. Mitchell, 'The Logic of Transnational Action: The Good Corporation and the Global Compact', (2007) 55 Political Studies 733-753; P. I. Blumberg, 'Asserting Human Rights Against Multinational Corporations under United States Law: Conceptual and Procedural Problems', (2002) 50 American Journal of
} 
principles $^{16}$ as well as social, labor ${ }^{17}$ and environmental ${ }^{18}$ standards in the context of trade agreements ${ }^{19}$ and finance arrangements ${ }^{20}$ : each field raises pertinent questions as to the possibilities of influencing the evolving governance structures with a view to protecting public interests and social, environmental and cultural values. Most certainly, the complexity of these challenges drives the general state of alert, in which policy makers, scholars, activists, community groups and NGOs have been for a long time, being engaged in political awareness building and analysis, policy development, agenda formulating and resistance. ${ }^{21}$ While for the "West" the globalization challenge continues to be analyzed above all against the background of an alleged erosion of state sovereignty ${ }^{22}$, the analysis offered by scholars focusing on indigenous peoples $^{23}$ as well as on constitutional developments in the "Global South" ${ }^{24}$ points to the significant asymmetries and omissions in this "post-national" narrative. ${ }^{25}$

Comparative Law 493-529; J. G. Ruggie, Just Business. Multinational Corporations and Human Rights (Norton, 2013).

${ }^{16}$ See the excellent discussion and analysis in A. W. Lang, World Trade Law after Neoliberalism. Re-imagining the Global Economic Order (Oxford University Press, 2011), 23-60.

${ }^{17}$ S. J. Powell/T. Low, 'Beyond Labor Rights: Which Core Human Rights Must Regional Trade Agreements Protect?', (2012) 12 Richmond Journal of Global Law and Business 91-188.

${ }^{18}$ D. Vogel, 'Trading up and governing across: transnational governance and environmental protection', (1997) 4 Journal of European Public Policy 556-571; S. P. Subedi, 'Balancing International Trade with Environmental Protection: International Legal Aspects of Eco-Labels', (1999) 25 Brooklyn Journal of International Law 373-405; K. Gordon/J. Pohl, 'Environmental Concerns in International Investment Agreements: a survey', (2011) OECD Working Papers on International Investment, No. 2011/1, OECD Investment Division http://www.oecd.org/daf/inv/investment-policy/48083618.pdf.

${ }^{19}$ J. Dine, 'Democratization: The Contribution of Fair Trade and Ethical Trading Movements', (2008) 15 Indiana Journal of Global Legal Studies 177-212; L. Bartels, 'Trade and Human Rights', in D. Bethlehem, D. McRae, R. Neufeld and I. Van Damme (eds), Oxford Handbook of International Trade Law (Oxford University Press, 2009), 571-596.

${ }^{20}$ B. J. Richardson, Socially Responsible Investment Law: Regulating the Unseen Polluters (Oxford University Press, 2008). See also the website: http://www.ussif.org/.

${ }^{21}$ C. Rodríguez-Garavito, 'Ethnicity.gov: Global Governance, Indigenous Peoples, and the Right to Prior Consultation in Social Minefields', (2011) 18 Indiana Journal of Global Legal Studies 263; K. H. Moahi, 'Globalization, Knowledge Economy and the implication for Indigenous Knowledge', (2007) 7 International Journal of Information Ethics 1-8.

${ }^{22}$ L. Henkin, 'That 'S' Word: Sovereignty, and Globalization, and Human Rights, et cetera', (1999) 68 Fordham Law Review 1-14; S. Dinah, 'Globalization and the Erosion of Sovereignty: Protecting Human Rights in a Globalized World', (2002) 25 Boston College Int'l \& Comp. L. Rev. 273; E. A. Posner, The Perils of Global Legalism (Chicago University Press, 2009).

${ }^{23}$ G. Pentassuglia, 'Towards a Jurisprudential Articulation of Indigenous Land Rights', (2011) 22 European Journal of International Law 165-202; L. A. Miranda, 'The Role of International Law in Intrastate Natural Resource Allocation: Sovereignty, Human Rights, and Peoples-Based Development', (2012) 45 Vanderbilt Journal of Transnational Law 785-840. Offering an insightful perspective on the emerging European discourse is: T. Koivurova, 'Jurisprudence of the European Court of Human Rights Regarding Indigenous Peoples: Retrospect and 
It is against this background that the original stage setting for our analysis will likely have to be revisited in a fundamental way. It is within a Western, post-nation state scenario that the question about the role of private law in an ever faster proliferating realm of "private" transnational regulatory governance unfolds against the growing concerns with the precariousness of maintaining public interest representation (so-called "input-legitimacy"26) pathways on a global level. From the Global South perspective, the red thread of the narrative which traces the rise of the nation-state from the middle-ages through nationalization and constitutionalization processes and two world wars towards the consolidation of an international political order of sovereign and equal nation states ${ }^{27}$ is in fact much more porous, ripped and stitched together throughout time, revealing a host of contestations, alternative paths and roads not taken. ${ }^{28}$ We can hardly overestimate the significance of the tensions in this constellation, which arise between the standard Western account of the nation-state and its claim to political sovereignty and economic competition on the one hand, and the challenging of that account through evidence of the omission, suppression, violence and asymmetry that really shaped the evolution of the international order, on the other. ${ }^{29}$ It is one of the greatest challenges in global governance research in general, and in legal theory in particular, to find a suitable, adequate way to address the relationship between "societal" and "political" ordering, between market and state, private

Prospects', in M. Fitzmaurice and P. Merkouris (eds), The Interpretation and Application of the European Convention of Human Rights: Legal and Practical Implications (Martinus Nijhoff Publishers, 2013), $217-257$.

${ }^{24}$ See the case studies on India, Colombia and South Africa in D. Bonilla (ed) Constitutionalism of the Global South (Cambridge University Press, 2012).

${ }^{25}$ A. Mbembe, On the Postcolony (University of California Press, 2001); B. S. Chimni, 'Third World Approaches to International Law: A Manifesto', (2006) 8 International Community Law Review 3-27; O. C. Okafor, 'Critical Third World Approaches to International Law (TWAIL): Theory, Methodology, or Both?', (2008) 10 International Community Law Review 371-378. See also S. Pahuja, Decolonising International Law. Development, Economic Growth and the Politics of Universality (Cambridge University Press, 2011).

${ }^{26}$ F. W. Scharpf, 'The viability of of advanced welfare states in the international economy. Vulnerabilities and options', (2000) 8 Eur. Rev. 399-425.

${ }^{27}$ W. Grewe, The Epochs of International Law [Michael Byers transl.] (Duke University Press, 2000).

${ }^{28}$ See the excellent analysis by A. Anghie, Imperialism, Sovereignty and the Making of International Law (Cambridge University Press, 2005). See, more recently, the fine investigation by S. Pahuja, 'Laws of encounter: a jurisdictional account of international law', (2013) 1 London Review of International Law 63-98.

${ }^{29}$ J.-M. Barreto, 'Decolonial Strategies and Dialogue in the Human Rights Field: A Manifesto', (2012) 3 Transnational Legal Theory 1-30; see also A. Orford, 'Muscular Humanitarianism: Reading the Narratives of the New Interventionism', (2003) 10 Eur. J. Int'l L. 679-711. 
and public, against the background of such contested framework narratives. But, while such context-sensitive work has been done for a while already in the realm of human rights theory in the context of a critical engagement with 'comparative legal traditions" ${ }^{, 30}$ and 'cultures ${ }^{, 31}$, promising evidence in the area of private regulatory governance, or in private law more generally, is still lagging behind. As private lawyers strive to underscore a normative foundation for their field, they point to private law's efforts in resisting the continuously forceful, neo-liberal thrust of the prevailing international economic order. ${ }^{32}$ Meanwhile, scholars who associate themselves with different strands of systems theory, regulation theory or critical theory focus on the messy-ness of the inchoate and highly decentralized landscape of transnational private regulatory governance 33 , rendering the boundaries between a "public" and a "private" law approach to economic globalization more ambiguous. In contrast then, the institutional and constitutionalist investigations by political scientists ${ }^{34}$ focus on questions of agency, interests, and accountability, and such studies find their echos, above all, in public and public international law scholarship. ${ }^{35}$ By contrast, private law and private law theory are, for the most part, still the missing voices here ${ }^{36}$, although the field has a rich tradition in critically

\footnotetext{
${ }^{30}$ H. P. Glenn, 'Comparative Legal Families and Comparative Legal Traditions', in M. Reimann and R. Zimmermann (eds), Oxford Handbook of Comparative Law (Oxford University Press, 2006), 421-440.

${ }^{31}$ U. Baxi, 'The Colonialist Heritage', in P. Legrand and R. Munday (eds), Comparative Legal Studies: Traditions and Transitions (Cambridge University Press, 2003), 46-75; U. Baxi, The Future of Human Rights (Oxford University Press, 2002); W. Twining, Human Rights, Southern Voices. Francis Deng, Abdullahi An-Na'im, Yash Ghai and Upendra Baxi (Cambridge University Press, 2009).

32 J. Basedow, 'The State's Private Law and the Economy: Commercial Law as an Amalgam of Public and Private Rule-Making', (2008) 56 American Journal of Comparative Law 703-721. For a critical perspective, see J. T. Gathii, 'Third World Approaches to International Economic Governance', in R. A. Falk, B. Rajagopal and J. Stevens (eds), International Law and the Future (Routledge Cavendish, 2008), 255-267, and Lang, World Trade Law after Neoliberalism, supra, note 16.

${ }^{33}$ For an excellent discussion, see the symposium introduction by C. Scott/F. Cafaggi/L. Senden (eds), The Challenge of Transnational Private Regulation: Conceptual and Constitutional Debates. Symposium Issue of the Journal of Law and Society, Vol. 38, No. 1, pp. 1-188 (Wiley-Blackwell, 2011). For an earlier assessment, see O. Perez, 'Normative Creativity and Global Legal Pluralism: Reflections on the Democratic Critique of Transnational Law', (2003) 10 Indiana Journal of Global Legal Studies 25-64. See also G.-P. Calliess/P. Zumbansen, Rough Consensus and Running Code: A Theory of Transnational Private Law (Hart Publishing, 2010), in particular chapters 2 and 5.

${ }^{34}$ J. G. Ruggie, 'Reconstituting the Global Public Domain - Issues, Actors, and Practices', (2004) 10 European Journal of International Relations 499-531.

${ }^{35}$ See only B. Kingsbury/N. Krisch/R. Stewart, 'The Emergence of Global Administrative Law', (2005) 68 Law \& Contemporary Problems 15-61.

${ }^{36}$ There are exceptions: see eg R. Wai, 'Transnational Private Law and Private Ordering in Contested Global Society', (2005) 46 Harvard International Law Journal 471-486, and D. Caruso, 'Private Law and State-Making in the Age of Globalization', (2006) 39 New York University Journal of International Law \& Politics 1-74.
} 
investigating the regulatory challenges that arise from a state's political apparatus responding to rapid societal and economic change. ${ }^{37}$ Furthermore, it seems obvious how the task to decipher the hybrid regulatory code of transnational governance would require a substantial contribution from scholars working in these traditions. ${ }^{38}$

I want to argue that the re-invigoration of private law within the political science and public law dominated discourses on global governance must occur against a background of a comprehensively reconceptualized framework of how we - and others - are speaking about globalization and the law in the first place. This reconceptualization is prompted by the significant challenges that post-colonial and third-world-approaches-to-international-law scholars have been formulating in response to the otherwise canonic and typical account of the Westphalian rise of the Western nation-state, its transformation in the twentieth century and the erosion of the nation-states' regulatory sovereignty in an increasingly globalized world of the twenty-first century. ${ }^{39}$ The post-colonial challenge in legal and political theory makes more than clear today that a re-invigoration of private law's abilities to "pierce the legal veil" in an attempt to render visible the social and economic inequalities that pervade the realities underneath the floorboards of rules and principles in legal argument ${ }^{40}$ can no longer take the troubled regulatory history of the Western welfare state as its obvious starting point and as its all determining frame

\footnotetext{
${ }^{37}$ See eg K. Llewellyn, 'What Price Contract? - An Essay in Perspective', (1930) 40 Yale Law Journal 704-751, and the recent assessment by H. Dagan, 'The Realist Conception of Law', (2007) 57 UTLJ 607-660.

${ }^{38}$ See eg G. Teubner, 'Global Private Regimes: Neo-spontaneous law and dual constitution of autonomous sectors in world society?', in K.-H. Ladeur (ed) Globalization and Public Governance (Ashgate, 2004), 71-87. See also P. Zumbansen, 'Law and Legal Pluralism: Hybridity in Transnational Governance', in P. Jurcys, P. F. Kjaer and R. Yatsunami (eds), Regulatory Hybridization in the Transnational Sphere (Martinus Nijhoff, 2013), 49-70. From a public \& constitutional law perspective, see C. Engel, 'Hybrid Governance Across National Jurisdictions as a Challenge to Constitutional Law', (2001) 2 European Business Organization Law Review [EBOR] 569-584, Preprints aus der Max-Planck-Projektgruppe Recht der Gemeinschaftsgüter Bonn 2001/8: http://www.mpprdg.mpg.de/pdf_dat/001_8.pdf, K.-H. Ladeur, 'Globalization and Public Governance - A Contradiction?', in K.-H. Ladeur (ed) Public Governance in the Age of Globalization (Ashgate, 2004), 1, and H. Farrell, 'Hybrid Institutions and the Law', (2002) 23 Zeitschrift für Rechtssoziologie 25-40.

${ }^{39}$ See eg J. T. Gathii, 'TWAIL: A Brief History of Its Origins, Its Decentralized Network, and a Tentative Bibliography', (2011) 3 Trade, Law and Development 26.

${ }^{40}$ R. L. Hale, 'Coercion and Distribution in a Supposedly Non-Coercive State', (1923) 38 Political Science Quarterly 470-494; D. Trubek, 'Toward a Social Theory of Law: An Essay on the Study of Law and Development', (1972) 82 Yale Law Journal 1-50; D. Kennedy, 'Form and Substance in Private Law Adjudication', (1976) 89 Harvard Law Review 1685-1778; P. Zumbansen, 'Introduction: Private Ordering in a Globalizing World: Still Searching for the Basis of Contract', (2007) 14 Indiana Journal of Global Legal Studies 181-190.
} 
of reference. The next order of the day must be to ironicize ${ }^{41}$, to relativize ${ }^{42}$ and to 'provincialize" ${ }^{43}$ the ever so sophisticated analysis of the decline of the regulatory (Western welfare) state in the $1970 \mathrm{~s}$ and $1980 \mathrm{~s}^{44}$ in order to more adequately interrogate the "publicprivate' divide - a pillar in the standard Western account of law's historical development ${ }^{45}-$ against the background of the present transnational context. Such a project, however, would go beyond what can even remotely be attempted in the confines of these brief remarks. Meanwhile, it helps to better understand the confined nature of most of the conversations about the legitimacy deficit in (private) global governance, if we take note of the fact that before long we will need to substantively widen our scope of analysis. ${ }^{46}$ In other words, it will no longer be enough to engage in efforts of patching the legitimacy deficits of transnational private regulatory governance solely against the background of a (Western) welfare state having experiencing dramatic erosions of his regulatory powers. Instead, in the years ahead we will need to critically engage with the phenomenon of private regulatory power against the background of a farreaching, post-colonial critique of the universalist accounts of the rise of the Westphalian international order (of sovereign nation states) and of their subsequent demise through "privatization, (Europeanization) and globalization."

\section{The Aspirational, Navigational Role of Lawyers in the Transnational Space}

\footnotetext{
${ }^{41}$ K. Rittich, 'Functionalism and Formalism: Their latest Incarnations in Contemporary Development and Governance Debates', (2005) 55 University of Toronto Law Journal 853-868, at 868. See also P. Zumbansen, 'Law After the Welfare State: Formalism, Functionalism and the Ironic Turn of Reflexive Law', (2008) 56 American Journal of Comparative Law 769-805.

${ }^{42}$ E. Darian-Smith, Laws and Societies in Global Contexts. Contemporary Approaches (Cambridge University Press, 2013).

${ }^{43}$ D. Chakrabarty, Provincializing Europe. Postcolonial Thought and Historical Difference, 2nd ed. [orig. 2000] (Princeton University Press, 2007).

${ }^{44}$ See only the contributions to G. Teubner (ed) Dilemmas of Law in the Welfare State (Walter de Gruyter, 1986).

45 See only C. Harlow, "'Public" and "Private" Law: Definition without Distinction', (1980) 43 Modern Law Review 241-265; D. Kennedy, 'The Stages of the Decline of the Public/Private Distinction', (1982) 130 University of Pennsylvania Law Review 1349-1357, and A. C. Cutler, 'Artifice, Ideology and Paradox: the Public/Private Distinction in International Law', (1997) 4 Review of International Political Economy 261-285.

${ }^{46}$ An area where this North-South dialogue has been taking place for quite some time, however, is international investment law: see eg the work by M Sornarajah, G van Harten or D Schneiderman.

${ }^{47}$ For such a standard narrative, see R. Michaels/N. Jansen, 'Private Law Beyond the State? Europeanization, Globalization, Privatization', (2007) 55 American Journal of Comparative Law 843-890.
} 
For the time being, the engagement with the legitimacy deficit of a proliferating, neo-liberal global order has been based on the 'rise-and-fall' narrative of the Westphalian order and its subsequent transformation into fragmented international legal regimes and hybrid, public-private governance arrangements. ${ }^{48}$ The explanation offered for the precarious stance of public values in the emergence of a market-driven sphere of global private self-regulation has had its regular origin in the alleged exhaustion of the nation state's regulatory capacity - with globalization merely accentuating and amplifying the state's inherent adaptation problems to complex social arrangements and financial pressures. ${ }^{49}$ In light of overwhelming, spatial regulatory challenges such as climate change, security, migration, poverty and hunger, legal theorists began translating the quite recently learned lessons from the death of the "regulatory state" 50 and the rise of its successor $^{51}$ into an evolving theory of global governance, which aspires to generate a multidisciplinary account of the challenges of globalization for political and legal theory. While scholarly contributions to that endeavor fill the metaphorical shelves of ever faster expanding online library resources ${ }^{52}$, we can - for the purposes of our present inquiry - distinguish between two broad strands in legal scholarship on this question, which turn out to largely correspond to alternatives in the underlying social-political theory. The rough demarcation, then, emerges as between what we may call "functionalist" and "normative" approaches to the analysis of law's role in a globalized world. While scholars sympathizing with the former approach seem more ready and willing to accept a high degree of world society's functional differentiation into specialized, self-regulating fields of activity (and corresponding rationality ${ }^{53}$ ), scholars who

\footnotetext{
${ }^{48}$ J. Klabbers, 'Of Round Pegs and Square Holes: International Law and the Private Sector', in P. Jurcys, P. F. Kjaer and R. Yatsunami (eds), Regulatory Hybridization in the Transnational Sphere (Martinus Nijhoff, 2013), 29-48.

${ }^{49}$ J. Habermas, 'The New Obscurity: The Crisis of the Welfare State and the Exhaustion of Utopian Energies [1985]', in J. Habermas (ed) The New Conservatism. Cultural Criticism and the Historians' Debate [ed. and transl. by Shierry Weber Nicholsen] (MIT Press, 1989), 48-70.

${ }^{50}$ G. Teubner, 'Regulatory Law: Chronicle of a Death Foretold', (1992) 1 Social \& Legal Studies 451.

${ }^{51}$ C. Scott, 'Regulation in the Age of Governance: The Rise of the Post Regulatory State', in J. Jordana and D. LeviFaur (eds), The Politics of Regulation: Institutions and Regulatory Reforms for the Age of Governance (Edward Elgar, 2004), 145-174.

${ }^{52}$ N. Krishnan/C. K. Das, 'Globalization and Challenges in Library Management in the 21st Century: An Appraisal of the University Library Systems in India and the USA', (2012) Challenges in Library Management System 381385 .

${ }^{53}$ G. Teubner, "Global Bukowina': Legal Pluralism in the World Society', in G. Teubner (ed) Global Law Without A State (Ashgate, 1997), 3-28; G. Teubner, 'Societal Constitutionalism: Alternatives to State-Centred Constitutional Theory?', in C. Joerges, I.-J. Sand and G. Teubner (eds), Constitutionalism and Transnational Governance (Hart
} 
endorse a normative stance have tended to highlight the dramatic risks of the loss of coherence and legitimacy in a fragmented global order. ${ }^{54}$

Regardless of the side on which scholars would see themselves in this dispute, each group would find itself struggling over at least a working definition of law in this global context. Again, the juxtaposition would follow well-known lines: while one group (the "normative" one) adhered to a model of law, which would be defined through an institutionalized framework to produce, enforce and adjudicate binding norms ${ }^{55}$, the other group - in a functionalist vein - would understand law, above all, as a process of stabilizing expectations. ${ }^{56}$ Meanwhile, complementing and complicating these accounts, we find two contentions about the nature of law, which shift the definitorial perspective towards an assessment of the long-term effects of legal governance. Here, we find, on the one hand, assertions whereby law primarily serves purposes of emancipation and should thus be associated with ideas of hope, liberation, "voice“), while law's character, as defined on the other hand, is governed by its function as oppressor, silencer and violent actor.

Now, the dramatic and sobering experience of those engaged in the functionalist-normative debate over law's role in global governance has been that these distinctions do not matter that much at the end of the day. From the perspective of ever faster evolving regimes of transnational private regulatory norms and standard setting - seen as potentially responding to a decline of state regulatory capacity by filling public goods gaps ${ }^{57}$ - it became more and more clear, that the second definitional approach of law's globalized nature might in fact be the most appropriate: law in a global context comes in many forms, shapes and sizes but its main function can be seen

Publishing, 2004), 3-28; A. Fischer-Lescano/G. Teubner, 'Regime-Collisions: The Vain Search for Legal Unity in the Fragmentation of Global Law', (2004) 25 Michigan Journal of International Law 999-1046.

${ }^{54}$ See the contributions to A. v. Bogdandy/I. Venzke (eds), International judicial lawmaking on public authority and democratic legitimation in global governance (Springer, 2012).

${ }^{55}$ A. Bogdandy/P. Dann/M. Goldmann, 'Developing the Publicness of Public International Law', (2008) 9 German Law Journal 1375-1400.

${ }^{56}$ N. Luhmann, A Sociological Theory of Law (Routledge Kegan \& Paul, 1985); G. Teubner, 'How the Law Thinks: Toward a Constructivist Epistemology of Law', (1989) 23 Law \& Society Review 727-758.

${ }^{57}$ C. Scott, 'Beyond Taxonomies of Private Authority in Transnational Regulation', (2012) 13 German Law Journal 1329-1338. See also the standard work by N. Brunsson/B. Jacobsson, A World of Standards (Oxford University Press, 2000). 
as consisting of stabilizing the expectations of its stakeholders. ${ }^{58}$ That, however, renders the original starting point of an ambiguous, complementary state of public and private law perspectives on global governance ever more poignant. Recognizing that the "public" rescue of private regulatory arrangements would have to occur in a context that we find increasingly difficult to assess on the basis of an all-encompassing, uncontested normative foundation such as a universalist human rights account, the bright line distinction between public and private begins to fade once more. In a fragmented global sphere, which is marked above all by existential contestations of normative stances, worthy interests, viable representation and political voice, there appears to be little room for a one-size-fits-all theory of global justice. Instead, in a gesture of denial, we may either resort to quasi-revisionist, post-Westphalian accounts of state sovereignty $^{59}$ which entirely ignore the post-colonial and indigenous contestation of the international legal order narrative or we can throw ourselves into the god-less and center-less realm of global functional differentiation, in which the stakes of a transnatoinal merchant community ${ }^{60}$ compete with the moral stakes raised by indigenous, epistemic and other situational communities. In that constellation, even a renewed interest in "power"61 is not likely to solve the differentiation conundrum we are faced with per se, but will have to take the diverse accounts of what constitutes societal, institutional, and structural power as a necessary starting point. The differentiation of human interactions and epistemes ${ }^{62}$ has rendered the normative landscape unpenetrable and unintelligible for any attempt to provide an exclusive, coherent account of who's "up","down", "right" or "wrong".

\footnotetext{
${ }^{58}$ For an elaboration of the nature of stakeholders in global normsetting in the form of "affected communities", see R. Cotterrell, 'Transnational Communities and the Concept of Law', (2008) 21 Ratio Juris 1-18, and R. Cotterrell, 'Spectres of Transnationalism: Changing Terrains of Sociology of Law', (2009) 36 Journal of Law and Society 481500.

${ }^{59}$ J. Goldsmith/E. Posner, The Limits of International Law (Harvard University Press, 2005); A. T. Guzman, How International Law Works. A Rational Choice Theory (Oxford University Press, 2008); E. A. Posner, The Perils of Global Legalism (Chicago University Press, 2009).

${ }^{60}$ E. Gaillard, Legal Theory of International Arbitration (Martinus Nijhoff Publishers, 2010); G. Teubner, "Global Bukowina': Legal Pluralism in the World Society', in G. Teubner (ed) Global Law Without A State (Ashgate, 1997), 3-28.

${ }^{61}$ But see R. Cotterrell, 'What is Transnational Law?', (2012) 37 Law \& Social Inquiry 500-524, esp. 513-514, and R. Cotterrell, 'Rethinking 'Embeddedness': Law, Economy, Community', (2013) 40 Journal of Law and Society 4967 , where RC critically revisits the usefulness of 'community' as an distinct organizational entity and shifts the emphasis towards 'social relations of community of various contrasting types' (id, at 55).

${ }^{62}$ N. Luhmann, Political Theory in the Welfare State [1981, transl. by John Bednarz Jr.] (Walter de Gruyter, 1990), and B. Latour, We have never been modern (Catherine Porter transl.) (Harvard University Press, 1993).
} 
That said, where can we situate today the ever more pressing anxieties about the legitimacy deficits of transnational private regulatory governance? It appears as if we are back to where we started from, with the only difference now being, that we realize that it is not just a simple choice between a 'functionalist' and a 'normative" theory of global regulatory governance. Instead, we see that the former gives expression to the undeniable degree of societal differentiation on a global scale, while the latter points to the complementing efforts to submit these processes to a critical engagement. While proponents of the systems theory account of societal differentiation would contend that such 'critical engagement' is impossible as there is no general outside vantage point from which such interrogation would be possible ${ }^{63}$, critical (legal, political) scholars (must) insist on a way in, behind and underneath this facade. ${ }^{64}$

Surely, and in light of the above described tensions, the main character of transnational legal governance must be defined as functionalist, in that law (along with various forms of "soft" law, norms, codes, standards, recommendations and guidelines) responds to the regulatoryorganizational challenges of complex fields of global interaction. Echoing the changing roles that lawyers have assumed in the context of transformed and globalized state functions in the twentieth century, transnational lawyers today must be at once litigators, policy makers, legislators and norm entrepreneurs, activists and community organizers. ${ }^{65}$ The nature, roles and functions of the transnational lawyer evolve in relation to the functional differentiation of their areas of engagement. With the rise of expert knowledge, the scrutiny of competing opinions and epistemes, law and legal consultancy fuses into a complex, multi-tiered enterprise of regulatory governance. And while the normative challenges arising from these developments accrue, the questions of how to adequately address them grow in complexity. ${ }^{66}$ Lawyers, stepping out of

\footnotetext{
${ }^{63}$ N. Luhmann, 'Quod omnes tangit: Remarks on Jürgen Habermas' Legal Theory', in M. Rosenfeld and A. Arato (eds), HABERMAS ON LAW AND DEMOCRACY: CRITICAL EXCHANGES 1998), 157-173.

${ }^{64}$ R. M. Unger, The Critical Legal Studies Movement (Harvard University Press, 1986); D. Kennedy, 'Law and the Political Economy of the World', (2013) 26 Leiden Journal of International Law 7-48.

${ }^{65}$ S. Bryant/J. K. Peters, 'Five Habits for Cross-Cultural Lawyering', in K. H. Barrett and W. H. George (eds), Race, Culture, Psychology, and Law (Sage, 2004), Ch. 4; L. C. Levin/L. Mather (eds), Lawyers in Practice: Ethical Decision Making in Context (University of Chicago Press, 2012); B. Garth, 'Introduction: Taking New Legal Realism to Transnational Issues and Institutions', (2006) 31 Law \& Soc. Inquiry 939-945.

${ }^{66}$ C. Scott, 'Regulating Everything', (2008) Inaugural Lecture, University College Dublin, School of Law, 26.2.2008 http:/geary.ucd.ie/mapping/images/Documents/RegEverything.pdf.
} 
their traditional roles of serving a client's interests and/or promoting the public interest, find themselves engaged in navigating ethnographies of competing stakes and interests ${ }^{67}$, mapping and identifying competences and authorities, formulating policy and identifying appropriate levels of regulation, contributing to the formulation and creation of adequate norms, while maintaining, overall, a highly functional, particularized outlook and focus. Lawyers as regulatory actors, then, operate in newly expanding frameworks, which evolve around the transformation, disaggregation $^{68}$ and transnationalization of municipal institutional safeguards and representation processes. ${ }^{69}$ International organizations, regulatory networks and regimes, hybrid governance institutions and shifting interest coalitions such as the " $\mathrm{G} 20$ ", but also grass-roots movements, community organizations and social movements ${ }^{70}$, as well as information and community building fora for new voices, new movements and actors such as the World Social Forum ${ }^{71}$ bring core political concerns around representation and 'affectedness', participation and accountability into sharp relief. $^{72}$ If a straight-forward, institutionally and normatively coherent, 'public' (rescue) response to the legitimacy woes of transnational private regulatory governance were possible, then how could such a response look like - in view of the diversified institutional and organizational landscape we just depicted? From which vantage point should we begin to look for answers to the question of who's in and who's out? Attempts to formulate responses are made from within a host of disciplinary, conceptual imaginations, including Global Administrative Law $^{73}$, Global Constitutionalism ${ }^{74}$ and Cosmopolitanism ${ }^{75}$, Regulatory Capitalism ${ }^{76}$ as well as

\footnotetext{
${ }^{67}$ D. A. Westbrook, 'Theorizing the Diffusion of Law: Conceptual Difficulties, Unstable Imaginations, and the Effort to Think Gracefully Nevertheless', (2006) 57 Harvard International Law Journal 489-505.
}

${ }^{68}$ A.-M. Slaughter, 'Disaggregated Sovereignty: Towards the Public Accountability of Global Government Networks', (2004) 39 Government and Opposition 159-190.

${ }^{69}$ S. Cassese, 'New paths for administrative law: A manifesto', (2012) 10 International Journal of Constitutional Law [I.Con] 603-613; A. C. Aman Jr., The Democracy Deficit (New York University Press, 2004).

${ }^{70}$ B. Rajagopal, 'International Law and Social Movements: Challenges of Theorizing Resistance', (2003) 41 Columbia Journal of Transnational Law 397-433.

${ }^{71}$ B. d. Sousa Santos, 'The World Social Forum and the Global Left', (2008) 36 Politics \& Society 247-270; J. C. Leite, The World Social Forum. Strategies for Resistance [transl. Traci Romine] (Haymarket Publishers, 2005).

${ }^{72}$ R. Kreide, 'The Ambivalence of Juridification. On Legitimate Governance in the International Context', (2009) 2 Global Justice: Theory Practice Rhetoric 18-34.

${ }^{73}$ B. Kingsbury, 'The Concept of 'Law' in Global Administrative Law', (2009) 20 Eur. J. Int'l L. 23-57; for a critical engagement, see C. Harlow, 'Global Administrative Law: The Quest for Principles and Values', (2006) 17 European Journal of International Law 187-214.

${ }^{74}$ J. L. Dunoff/J. P. Trachtman, 'A Functional Approach to Global Constitutionalism', in J. L. Dunoff and J. P. Trachtman (eds), Ruling the World? Constitutionalism, International Law and Global Governance (Cambridge 
Transnational Governance. ${ }^{77}$ Offering rich accounts of the institutional and normative conundrum presented by law's entanglement with globalization, this scholarship can no longer easily be categorized as either descriptive or prescriptive, an observation which seems to confirm our previous contention that it is unlikely to find a "quick fix" for the increasingly detailed accounts of regulatory differentiation and ever more pressing normative questions.

\section{Private Law's Role in the Transnational Space: Complicity or Resistance?}

So, what can be "done"? The continuing proliferation of transnational private regulatory governance raises dramatic challenges to conceptions of legal authority, legitimacy and public regulation of economic activity. The pace at which these developments occur is set by a coalescence of multiple regime changes, predominantly in commercial law areas ${ }^{78}$, but also in the field of internet governance ${ }^{79}$, corporate law $^{80}$ and labor law ${ }^{81}$, where the rise to prominence

University Press, 2009), 3-35, and C. E. J. Schwöbel, 'The Appeal of the Project of Global Constitutionalism for Public International Lawyers', (2012) 13 German Law Journal 1-21.

${ }^{75}$ D. Held, 'Cosmopolitanism', (2006) Stanford Encyclopedia of Philosophy (28 November 2006) http://plato.stanford.edu/entries/cosmopolitanism. See also A. Stone Sweet, 'Constitutionalism, Legal Pluralism, and International Regimes', (2009) 16 Indiana Journal of Global Legal Studies 621-645.

${ }^{76}$ J. Braithwaite, Regulatory Capitalism. How it Works, Ideas for Making it Work Better (Edward Elgar, 2008); Levi-Faur, supra, note 7.

${ }^{77}$ See the contributions to T. Hale/D. Held (eds), Handbook of Transnational Governance. Institutions and Innovations (Polity Press, 2011).

${ }^{78}$ T. Schultz, 'Does Online Dispute Resolution Need Governmental Intervention? The Case for Architectures of Control and Trust', (2004) 71 North Carolina Journal of Law \& Technology 71-106; G.-P. Calliess, 'Transnational Civil Regimes: Economic Globalization and the Evolution of Commercial Law', in V. Gessner (ed) Contractual Certainty in International Trade. Empirical Studies and Theoretical Debates on Institutional Support for Global Economic Exchanges (Hart Publishing, 2009), 215-238.

${ }^{79}$ A. B. Albarran/D. H. Goff (eds), Understanding the Web: Social, Political, and Economic Dimensions of the Internet (Iowa State Press, 2000); C. Engel, 'The Role of Law in the Governance of the Internet', in: Preprints of the Max Planck Project Group Law of Common Goods 2002/13, Bonn available at: http://www.mpprdg.mpg.de/pdf_dat/2002_13.pdf.

${ }^{80}$ A. N. Licht, 'The Mother of all Path-Dependencies: Towards a Cross-Cultural Theory of Corporate Governance Systems', (2001) 26 Delaware Journal of Corporate Law 147-205; C. Gerner-Beuerle, 'Determinants of Corporate Governance Codes', (2014) LSE Law, Society and Economy Working Papers 5/2014 http://ssrn.com/abstract=2346673.

${ }^{81}$ K. v. W. Stone, 'Labour in the Global Economy: Four Approaches to Transnational Labour Regulation', in J. McCahery, W. W. Bratton, S. Picciotto and C. Scott (eds), International Regulatory Competition and Coordination. Perspectives on Economic Regulation in Europe and the United States (Clarendon Press, 1996), 445-477; H. W. Arthurs, 'Reinventing Labor Law for the Global Economy: The Benjamin Aaron Lecture', (2001) 22 Berkeley Journal of Employment and Labor Law 271-294. 
of private actors has become a defining feature of the evolving transnational regulatory landscape. One of the most belabored fields, the transnational law merchant or, lex mercatoria, for some time had assumed the status of a poster child, as it represented a laboratory for the exploration of "private" contractual governance in a context, in which the assertion of public or private authority had itself become contentious. ${ }^{82}$ The ambiguity surrounding many forms of today's contractual governance in the transnational arena echoes that of the far-reaching transformation of public regulatory governance, which has been characteristic of Western welfare states over the last few decades. What is particularly remarkable, however, is the way in which the depictions of "private instruments" and "public interests" in the post-welfare state regulatory environment have given rise to a rise in importance of social norms, self-regulation and a general anti-state affect in the assessment of judicial enforcement or administration of contractual arrangements. ${ }^{83}$ As noted above with regard to the deep contestations of established narratives of modernization, progress and universalization, a central challenge resulting from case studies such as the transnational law merchant is from which perspective we ought to adequately study and assess the justifications that are being offered for a contractual governance model, which itself prioritizes and seeks to insulate "private" arrangements from their embeddedness in regulated market contexts, on both the national and transnational level.

It seems obvious by now, that to contend ourselves with a recurring focus on the law/non-law nature of the lex mercatoria ${ }^{84}$ falls short of grasping the more important question, namely, why this distinction matters and what the stakes are of searching for a solution in this context. To be sure, striving to either ascertain or to reject the legal nature of the predominantly "self-made"

\footnotetext{
${ }^{82}$ G.-P. Calliess, 'Lex Mercatoria: A Reflexive Law Guide To An Autonomous Legal System', in: 2 German Law Journal 17 (1 November 2001) available at: http://www.germanlawjournal.com/article.php?id=109; A. C. Cutler, Private Power and Global Authority: Transnational Merchant Law in the Global Economy (Cambridge University Press, 2003).

${ }^{83}$ Representative is law \& economics' rather ahistorical 'discovery" of "social norms": E. A. Posner, Law and Social Norms (Harvard University Press, 2000). R. C. Ellickson, 'Law and Economics Discovers Social Norms', (1998) 27 Journal of Legal Studies 537-565. Critical: S. Macaulay, 'Relational Contracts Floating on a Sea of Custom? Thoughts about the Ideas of Ian Macneil and Lisa Bernstein', (2000) 94 Northwestern University Law Review 775 804.

${ }^{84}$ See the altogether unproductive dispute between G. Teubner, "Global Bukowina': Legal Pluralism in the World Society', in G. Teubner (ed) Global Law Without A State (Ashgate, 1997), 3-28 and A. Cordes, 'The Search for a Medieval Lex Mercatoria', (2003) 5 Oxford University Comparative Law Forum http://ouclf.iuscomp.org/articles/cordes.shtml.
} 
norms of the lex mercatoria redirects attention to the setting and context in which legal norms are created, enforced and adjudicated. From a traditional perspective, such questions have regularly been raised with reference to dimensions of legality, on the one hand, and legitimacy, on the other. ${ }^{85}$ In response, I contend that what appears to be emerging from the alluded-to rise in importance of private as well as hybrid actors engaged in transnational norm production, standards, guidelines, codes and best practices, however, is a new concept of "context". Whereas much of legal theory and philosophy, especially in the analytical tradition, chose to scrutinize the nature of law and legal ordering without taking a greater interest in the context or environment, in which legal ordering as well as social conflicts occur, a legal pluralist account of law challenges such an approach in a fundamental way. Once the reference framework, illustrated by assertions of the "rule of law", "legal unity", "normative hierarchy" or the "separation of powers" becomes questionable in a global setting, law's relation to its 'outside', its context, as it were, moves into the center of analysis. From that perspective, the legal pluralist critique of the monist model of legal ordering ${ }^{86}$ can productively inform the analysis of transnational law. The law-state nexus, which has for so long been one of the centrally underlying assumptions at least in 'Western', 'Northern' legal epistemology, becomes relativized to the degree that regulation through law becomes 'de-centred' (J.Black). This de-centering of state-originating law into highly specialized fields of norm production had long marked the transformation of the welfare state and is further propelled and amplified by the transnationalization of law. ${ }^{87}$ These developments, as long as they were conceived to be taking place within a more or less institutionalized nation state setting prompted legal sociologists to question law's and lawyers' grasp of the reality in which legal decisions were being made, norms produced and their effectiveness measured. ${ }^{88}$ The legal sociological contribution to a fundamental critique of law

\footnotetext{
${ }^{85}$ K. Schmidt, 'Lex mercatoria: Allheilmittel? Rätsel? Chimäre?', in J. Murakami, H.-P. Marutschke and K. Riesenhuber (eds), Globalisierung und Recht: Beiträge Japans und Deutschlands zu einer internationalen Rechtsordnung im 21. Jahrhundert (Walter de Gruyter, 2007), 153-174.

${ }^{86}$ P. Fitzpatrick, 'Law and Societies', (1984) 22 Osgoode Hall Law Journal 115-138; R. MacDonald, 'Whose Access? Which Justice?', (1992) 7 Canadian Journal of Law \& Society 175; B. d. Sousa Santos, Toward a New Legal Common Sense: Law, Globalization, and Emancipation (Cambridge University Press, 2002).

${ }^{87}$ P. Zumbansen, 'Transnational Legal Pluralism', (2010) 1 Transnational Legal Theory 141-189 (http://ssrn.com/abstract=1542907).

${ }^{88}$ R. Cotterrell, 'Why Must Legal Ideas Be Interpreted Sociologically?', (1998) 25 Journal of Law \& Society 171192.
} 
can hardly be overstated, and the current interdisciplinary engagement with transnational law and regulatory governance must be seen as a continuation of these approaches. ${ }^{89}$

As a result, the "context" in which the analysis of law, its foundations and its effectiveness takes place is itself one which cannot simply be 'seen" ${ }^{90}$ or taken for granted when contemplating the legal nature of regulatory norms. Instead, context has become a factor that forms a crucial part of our assessment of the legal nature of the norms and their processes of creation and implementation under consideration. For example, a simple distinction between a "national" and a "global" context of law does not go far enough in addressing the correlation between a theory of law and a theory of the context in which law is embedded. Precisely because processes of 'globalization' or 'transnationalization' have decentered, relativized and provincialized the prior assumed role of the state in the production of legal norms, we need to scrutinize the new environment in which norms are being created and their nature ascertained.

Such a shift of perspective has far-reaching consequences for legal theory and for the philosophy of law but also for legal doctrine, in that many of the routinely assumed institutional frameworks for references to "public" or "private" law, for example, constitutional and administrative law on the one hand, contract, labor or corporate law on the other, can be seen in a new light. With the prevailing unavailability of a 'world government', or a 'global constitution', lawyers find themselves not only in an unavoidable, but necessary conversation with other disciplines. Such conversations concern the nature and structure of a sphere, which continues to be depicted through labels that hide rather than reveal the disciplinary grounding of the analytical assessment. References to "global governance", "world society" or "global constitutionalism" abound, but their definitional scope might appear less targeted than would likely be desired by those hoping to gain a clearer understanding of the consequences of globalization for their respective discipline. At the same time, the promise of such conceptual labels should be seen to lie in the opening up of perspectives that they generate. Global governance, arguably, is a term

\footnotetext{
${ }^{89}$ D. Nelken, 'Transnational Legal Processes and the (Re)construction of the 'Social': The Case of Human Trafficking', in D. Feenan (ed) Explorin the 'Social' of Socio-Legal Studies (Palgrave Macmillan, 2013), 137-156; P. Kotiswaran, 'Do Feminists Need an Economic Sociology of Law?', (2013) 40 Journal of Law and Society 115-136.

${ }^{90}$ That, however, is the contention of R. Michaels, 'Globalization and Law: Law Beyond the State', in R. Banakar and M. Travers (eds), Law and Social Theory (2nd ed.) (Hart Publishing, 2013), 287-303

(http://scholarship.law.duke.edu/faculty_scholarship/2862), 303.
} 
with a predominantly operational function within a political science framework, but it is by no means limited to the categories and concepts of that discipline. Instead, global governance cuts across disciplinary boundaries in that it pushes established frameworks ("politics"), distinctions ("public"/"private"), instruments ("elections") and concepts ("sovereignty") to extreme limits, at which point it becomes obvious how this strain on the architecture of one discipline is echoed and similarly resounds in other disciplines as they are dealing with pressures of globalization. From that perspective, global governance becomes a formula with which we can depict changes internal to respective disciplinary frameworks on the one hand, and through which we can verbalize the coalescing and overlapping of different disciplinary perspectives in a collaborative effort to make sense of the transformations associated with globalization, on the other.

What then, however, can or should be the role of law? Earlier in this chapter, we identified the dominant definition to be a functionalist one, a definition which holds law to be concerned, above all, with the stabilization of (highly heterogeneous) expectations of various stakeholders. At the same time, it is possible then to generalize the place of such defined law in the context of globalization. I contend that under conditions of globalization, "law" assumes the role of providing for a particular perspective on regulatory governance. The latter is no longer fully consumed under the heading of law, but must instead be deconstructed through different disciplinary lenses, only one of which is "law". In light of the functionalist rule of law framework on the global level that we identied earlier, say, with respect to the regulation of global financial markets ${ }^{91}$ or the protection of social rights ${ }^{92}$, the simultaneously increasing proliferation of private agency in the creation of governing norms and their dissemination ${ }^{93}$ causes a considerable constitutional itch. It comes as no surprise, then, that from a host of disciplinary, descriptive as well as prescriptive perspectives, the prospects of a "legal" framework for global governance have themselves become a major concern. Ranging from law to sociology, political science, geography and political philosophy, law's disembeddedness from

\footnotetext{
${ }^{91}$ See eg M. S. Barr/G. P. Miller, 'Global Administrative Law: The View from Basel', (2006) 17 European Journal of International Law 15-46.

92 S. Deakin, 'Social Rights in a Globalized Economy', in P. Alston (ed) Labour Rights as Human Rights (Oxford University Press, 2005), 25-60.

${ }^{93}$ See for example, Tim Büthe \& Walter Mattli, The New Global Rulers. The Privatization of REGULATION IN THE WORLD ECONOMY (2012).
} 
the nation-state prompts inquiries into the possibilities of 'reembedding' law or, alternatively, transposing and translating nation-state-"tested" frameworks and categories of legal regulation into the global governance context. ${ }^{94}$ Whatever might be the outcome in the short- or longterm, 'law's empire' has come under considerable pressure by having to reassess its role and its bearing in a complex regulatory and normative environment.

\section{E. Law and Society: A View from Everywhere - or, Nowhere?}

Just to be sure, the ongoing disputes over law's global role, including its institutional and normative dimensions - however these may be contested as non-universalist - occur in the context of deep-running divides between competing theories of society and social organization. And, it is against that background that the so far offered observations with regard to the contested legal nature of transnational private regulatory governance are but stand-ins or echoes of much larger concerns with the fundamental transformation of legal regulation today. As we saw, the contentions concerning, for example, lex mercatoria's "autonomy" and the legal nature of its norms then illustrate the pressure that the continuing societal differentiation and an increasingly fragmented regulatory transnational fabric creates for legal doctrine, terminology and concepts. This suggests, then, that questions such as those pertaining to the legal versus nonlegal nature of norms - which are clearly central not only to lex mercatoria but to the phenomena of transnational private regulatory governance more generally - are pointers to the more pressing and previously alluded to need to fundamentally rethink and re-imagine the relationship between law and society in light of a loosening state-law nexus. From this perspective, it becomes a necessity for legal scholars to consider theories of society when making statements about the quality and function of legal norms.

Importantly, such questions are not in any way new to law and legal scholars. Over time, the need to adapt law, its theory, doctrine and instruments to ever-changing societal conditions has only grown. And, however contested law's place and contribution to such changes became, such investigations regularly unfolded with a view to the ambivalent, constantly changing relations

\footnotetext{
${ }^{94}$ S. Frerichs, 'From Credit to Crisis: Max Weber, Karl Polanyi, and the Other Side of the Coin', (2013) 40 Journal of Law and Society 7-26.
} 
between law and the state. Regarding the latter, depictions of the role of the state shifted between ruler and protector, mediator and facilitator, long before state transformation would become a topic of studying the impact of globalization on law. ${ }^{95}$ For an emerging transnational legal theory, then, it will be decisive to learn how to engage with the lessons of the nation-state as well as with the increasing calls for their provincialization. An engagement with the regulatory experiences of the Western rule of law and welfare state of the twentieth century remains crucial in light of the fact that the nation state provided the institutional, but also the discursive context in which law's role was negotiated, contested and continually re-defined. The content and reach of such lessons, however, depends on the degree to which it is possible to simultaneously reflect on the underlying theory of society. As noted earlier, we need to distinguish between the institutional and normative stakes of a state/society model ${ }^{96}$, on the one hand, and those of concept which challenges the hierarchy-model of "state and society" by emphasizing the dynamics of co-evolving rationality systems (such as the economy, politics, religion, art, or law) in the context of a functionally differentiated (world) society, on the other. Such a distinction remains significant as it helps us to see more clearly the degree to which much of the current Western legal response to globalization has so far been shaped by a narrow account of state formation and subsequent changes. While this challenge lurks beneath the contemporary preoccupation with the perceived gap between a functionally minded mode of transnational regulatory governance and normative contentions of justice, this is not always easy to recognize and even more difficult to address. The reasons for this contraction in view can be found in law's struggle with the overwhelming evidence of functionally differentiated societal activities. ${ }^{97}$ While in the context of the nation state, law was primarily tasked with stabilizing both institutional and normative expectations ${ }^{98}$, its role in a differentiated world society appears to be undermined and relativized. Central to this shift is a reorientation of the function foremost

\footnotetext{
${ }^{95}$ Philip Abrams, Notes on the Difficulty of Studying the State, 1 J. OF HIST'L SociO. 58 (1988); Michel-Rolph Trouillot, The Anthropology of the State in the Age of Globalization: Close Encounters of the Deceptive Kind, 42 CURRENT ANTHROPOLOGY, 125 (2001).

${ }^{96}$ E.-W. Böckenförde, 'The Significance of the Distinction between State and Society in the Democratic Welfare State of Today', in E.-W. Böckenförde (ed) State, Society and Liberty. Studies in Political Theory and Constitutional Law (J.A. Underwood transl.) (Berg, 1991), 147-174.

${ }^{97}$ H. Willke, SMart GovernanCE. Governing THE GLOBAL KNOWLEDGE SOCIETy (CAMPUS, 2007).

${ }^{98}$ P. Zumbansen, 'Law After the Welfare State: Formalism, Functionalism and the Ironic Turn of Reflexive Law', (2008) 56 American Journal of Comparative Law 769-805 (2008).
} 
ascribed to law: rather than stabilizing normative expectations, the law can now be seen as having to stabilize, above all, cognitive expectations. In other words, when no societal system can claim normative superiority or primacy before another, law - from the perspective of systems theory - becomes a broker, a mediator and translator of competing, intersecting bodies of knowledge. ${ }^{99}$ One consequence of this reorientation is law's turn to an openness of goals, as its primary function is no longer defined - as from a critical theory perspective ${ }^{100}$ - as one to bring about desired (normative) results, but to open up, to facilitate, institutionalize and consolidate learning opportunities. ${ }^{101}$ Seen through this lens, the primary task for law is to reflexively facilitate the mediation of and between possibly very diverse and complex societal rationalities, without being able, in that process, to rely on previously established, hierarchically structured ordering patterns. ${ }^{102}$

It is difficult to overstate the methodological consequences of this shift of perspective, from which law is seen to assume a fundamentally different role than that, which we would ascribe to it on the basis of both a positivist, Kelsenian, or a normative, Fullerian or Dworkinian, model. If law's function could adequately be described as one of mediating, translating, and brokering competing and conflicting societal rationalities and meanings, the question with regard to law's proper core would become urgent. This concern with an allegedly fundamental and inherent

\footnotetext{
${ }^{99}$ G. Teubner, 'Altera pars audiatur: Law in the Collision of Discourses', in R. Rawlings (ed) Law, Society and Economy (Oxford University Press, 1997), 149-176.

${ }^{100}$ E. Blankenburg, 'The Poverty of Evolutionism: a critique of Teubner's case for 'reflexive law", (1984) 18 Law \& Society Review 273-289; and Teubner's response: G. Teubner, 'Autopoiesis in Law and Society: A Rejoinder to Blankenburg', (1984) 18 Law \& Society Review 291-301.

${ }^{101}$ N. Luhmann, 'Die Weltgesellschaft', (1970) 57 Archiv für Rechts- und Sozialphilosophie 1 (1970), reprinted in LUHMANN, SOZIOLOGISCHE AUFKLÄRUNG 2 (2nd ed., 2005) 51-71, at 55: "Kognitives Erwarten sucht sich selbst, normatives Erwarten sucht sein Objekt zu ändern. Lernen oder Nichtlernen - das ist der Unterschied."

${ }^{102}$ K.-H. Ladeur, 'Die rechtswissenschaftliche Methodendiskussion und die Bewältigung des gesellschaftlichen Wandels', (2000) 64 RabelsZ 60-103 (2000); id., Constitutionalism and the State of the 'Society of Networks': The Design of a New 'Control Project' for a Fragmented Legal System, 2:4 TRANSNATIONAL LEGAL THEORY 463-476 (2011). See also Luhmann, Weltgesellschaft, previous note, at 57: "Offensichtlich ist mit Hilfe der normativen Mechanismen, vor allem des Rechts, auf der Ebene politisch konstituierter Regionalgesellschaften eine evolutionär unwahrscheinliche Hochleistung stabilisiert und damit erwartbar gemacht worden - nämlich die verlässliche Motivation zu nahezu beliebig spezialisierbarem Handeln. [...] Es könnte sein, daß diese eigentümliche Kombination von Recht und Politik gerade in ihrer besonderen Leistungsfähigkeit eine Fehlspezialisierung der Menschheitsentwicklung war, die sich, vorläufig jedenfalls, nicht auf das System der Weltgesellschaft übertragen lässt."
} 
normative orientation of law ${ }^{103}$ becomes the more pressing the more law is placed on the same level as other forms of societal communication - as a systems theory approach would suggest.

\section{F. Transnational Private Regulatory Governance and the Empty Place of Politics?}

In light of the foregoing, it would appear that there are significant obstacles for a political, "critical" engagement with the ideological underpinnings of the purportedly market-oriented thinking which characterizes much of today's discourse around transnational economic governance. Not only are many of the avenues of political will formation and contestation which have developed in the state's constitutional system unavailable in the context of transnational regulatory regimes ${ }^{104}$, but the interest constellations of 'affected' parties and stakeholders in many of the instances alluded to before are of such complexity that traditional political discourse does not seem adequately equipped to provide this diversity with consequential voice.

Against this background, then, it seems that there is some merit in drawing on learning experiences with legal-political critique and legal sociological insights from within the nation state as we ascertain the opportunities for a political critique of the fragmented, transnational regulatory governance landscape. In particular, the insights from 'post-interventionist', 'postregulatory' law ${ }^{105}$ as these theoretical approaches evolved in response to the transformation of the Western welfare state ${ }^{106}$ during the last decades of the twentieth century, relate to the far reaching proliferation of alternative and hybrid forms of regulation. These transformations have

\footnotetext{
${ }^{103}$ See only L. Fuller, The Morality of Law (Yale University Press, 1964).

${ }^{104}$ For a fine analysis of the transnational realm, see D. Caruso, 'Private Law and State-Making in the Age of Globalization', (2006) 39 New York University Journal of International Law \& Politics 1-74 (2006).

${ }^{105}$ Gunther Teubner, Regulatory Law: Chronicle of a Death Foretold, 1 SociAL \& LEGAL STUDIES 451-475 (1992) [orig.: G. Teubner, 'Regulatorisches Recht: Chonik eines angekündigten Todes', (1992) ARSP Beiheft 54 140-161]; hereto, see P. Zumbansen, 'Post-regulatorisches Recht: Chronik einer angekündigten Karriere', in G.-P. Calliess, A. Fischer-Lescano, D. Wielsch and P. Zumbansen (eds), Soziologische Jurisprudenz. Festschrift für Gunther Teubner zum 65. Geburtstag (Walter de Gruyter, 2009), 629-643, English version: Post-regulatory Law: Chronicle of a Career Foretold, Faculty Seminar Presentation, McGill University, Faculty of Law, 18 February 2009, available at: http:/www.mcgill.ca/files/legal-theory-workshop/PZumbansen_Post-Regulatory-Law.pdf (last accessed: 16 February 2014).

${ }^{106}$ G. Teubner, 'Autopoiesis in Law and Society: A Rejoinder to Blankenburg', (1984) 18 Law \& Society Review 291-301 (1984).
} 
left deep imprints in law in general, but particularly in the taught and practiced discipline of administrative law. ${ }^{107}$ At the same time, private law scholars have been very prolific in tracing and further theorizing the shifts between public and private governance forms, which have greatly increased over the past decades. ${ }^{108}$

This constellation, arguably, offers considerable opportunities also for a critical-political engagement, which at first sight seemed elusive from the perspective of a sociological account of the world society. ${ }^{109}$ In the larger context of the field that has been referred to a number of times so far in this chapter - lex mercatoria - such opportunities for contestation have become more frequent. In this respect, prominent and lively fields of engagement include bilateral investment treaties $^{110}$, financial regulation ${ }^{111}$ and corporate law ${ }^{112}$, in 'law and development ${ }^{113}$ as well as the

${ }^{107}$ See e.g. M. Schmidt-Preuss, 'Verwaltung und Verwaltungsrecht zwischen gesellschaftlicher Selbstregulierung und staatlicher Steuerung', (1996) 56 Veröffentlichungen der Vereinigung der Deutschen Staatsrechtslehrer 160-234 (1996); A. C. Aman Jr., 'Administrative Law for a New Century', in M. Taggart (ed) The Province of Administrative Law (Hart Publishing, 1997), 90-107; T. Vesting, 'Zwischen Gewährleistungsstaat und Minimalstaat: Zu den veränderten Bedingungen der Bewältigung öffentlicher Aufgaben in der 'Informations- oder Wissensgesellschaft", in W. Hoffmann-Riem and E. Schmidt-Assmann (eds), Verwaltungsrecht in der Informationsgesellschaft (Nomos, 2000), 101-131.

${ }^{108}$ R. Wiethölter, 'Die Wirtschaftspraxis als Rechtsquelle', in P. Bockelmann (ed) Das Rechtswesen - Lenker oder Spiegel der Gesellschaft? (Piper, 1971), 165-185; R. Wiethölter, 'Recht-Fertigungen eines Gesellschafts-Rechts', in C. Joerges and G. Teubner (eds), Rechtsverfassungsrecht. Recht-Fertigung zwischen Privatrechtsdogmatik und Gesellschaftstheorie (Nomos, 2003), 11-22.

${ }^{109}$ See Marc Amstutz, Ibi Societas, Ibi Ius: The Conundrum of the Concept of World Law. Comments on Calliess \& Zumbansen, Rough Consensus and Running Code: A Theory of Transnational Private Law (Hart: 2010, paperback 2012), MANUSCRIPT FOR ROUGH CONSENSUS AND RUNNING CODE WORKSHOP, European University Institute, Florence, 13 May 2011, at 7.

${ }^{110}$ M. Sornarajah, 'Power and Justice:Third World Resistance in International Law', (2006) 10 Singapore Yearbook of International Law 19-57 (2006); G. Van Harten/M. Loughlin, 'Investment Treaty Arbitration as a Species of Global Administrative Law', (1006) 17 European Journal of International Law 121-150 (2006); G. K. Foster, 'Foreign Investment and Indigenous Peoples: Options for Promoting Equlibrium between Economic Development and Indigenous Rights', (2012) 33 Michigan Journal of International Law 627-691.

${ }^{111}$ See e.g. the description of transnational financial regulation by J. Black/D. Rouch, 'The development of global markets as rule-makers: engagement and legitimacy', (2008) Law and Financial Markets Review 218-233 (2008).

${ }^{112}$ See e.g. L. Catá Backer, 'The OECD Guidelines for Multinational Corporations: Using Soft Law to Operationalize a Transnational System of Corporate Governance', (2009) Law at the End of the Day (Blog) http://lcbackerblog.blogspot.com/2009/03/oecd-guidelines-for-multinational.html (last accessed: 1 December 2012), and G. Shaffer, 'On Terence C. Halliday and Bruce G. Carruthers, Bankrupt: Global Lawmaking and Systemic Financial Crisis. Stanford, Stanford University Press, 2010 Panel at the SASE 2010 Annual Meeting, Philadelphia, USA', (2011) Socio-Economic Review 1-24 (2011).

${ }^{113}$ K. Rittich, 'Functionalism and Formalism: Their latest Incarnations in Contemporary Development and Governance Debates', (2005) 55 University of Toronto Law Journal 853-868 (2005), and SUNDHYA PAHUJA, DECOLONISING INTERNATIONAL LAW (2011). 
growing intensification in transnational human rights litigation in the context, for example, of mining operations in Latin America or North Africa. ${ }^{114}$ These efforts are of particular importance in our context, as they testify to both inroads and challenges in connecting discourses with a focus on nation-state based changes in regulatory governance with those which at first sight appear to be of a distinctly, if not exclusively global and transnational nature.

To be sure, international economic law is deeply impregnated by the socio-economic imagination of market governance and as such sits only uneasily with regard to a confinement to territorial boundaries or, levels of governance. ${ }^{115}$ With a view to the just- referenced areas in international economic law, we can witness a growing number of efforts to initiate and consolidate processes of political and legal advocacy ${ }^{116}$, all of which seem to be characterized above all by a focus on process, facilitation of discourse and contestation, but not on a however narrowly defined set of principles or values. ${ }^{117}$ These examples testify to a significant opening up of opportunities for legal-political critique. To the degree, however that governance challenges are identified as emerging on either a national or a global level, the relevance of approximating 'national' and 'transnational' governance discourses ${ }^{118}$ lies in making visible the parallels between struggles in both spheres over an adequate identification and representation of affected "interests". Here, and there, the question is how to identify and to verbalize what is at stake and, for whom. And yet, in light of the foregoing, to place the question, 'What is at stake?' at the center of such a parallel reading of national and transnational governance discourses is

\footnotetext{
${ }^{114}$ See e.g. Rodríguez-Garavito, supra, note 21; see also C. Kamphuis, 'Canadian Mining Companies and Domestic Law Reform: A Critical-Legal Account', (2012) 13 German Law Journal 1459, and S. L. Seck, 'Home State Regulation of Environmental Human Rights Harms As Transnational Private Regulatory Governance', (2012) 13 German Law Journal 1363-1385.

${ }^{115}$ I. Bache/M. Flinders (eds), Multi-level Governance (Oxford University Press, 2004).

${ }^{116}$ See C. Kamphuis, 'Canadian Mining Companies and Domestic Law Reform: A Critical-Legal Account', (2012) 13 German Law Journal 1459, and S. L. Seck, 'Home State Regulation of Environmental Human Rights Harms As Transnational Private Regulatory Governance', (2012) 13 German Law Journal 1363-1385.

${ }^{117}$ See Rodríguez-Garavito, supra note 21; see also Boaventura de Sousa Santos, Beyond Abyssal Thinking (2007) EUROZINE, available at: http://www.eurozine.com/articles/2007-06-29-santos-en.html (last accessed: 1 December 2012); Larry Catá Backer, The United Nations' “Protect-Respect-Remedy” Project: Operationalizing a Global Human Rights Based Framework for the Regulation of Transnational Corporations, 9 ST. CLARA J. INT’L. L. 37 (2011).

118 S. Sassen, 'Globalization or denationalization?', (2003) 10 Review of International Political Economy 1-22; P. Zumbansen, 'Neither 'Public' nor 'Private', 'National' nor 'International': Transnational Corporate Governance from a Legal Pluralist Perspective', (2011) 38 Journal of Law \& Society 50-75.
} 
enormously ambitious, if not ill-directed. Because, what should be the reference point for the related assertion of those interests that testify to what is at stake? How can we assume to identify the correct starting point in a world of contested identities and meanings?

\section{G. Transnational Private Regulatory Governance: Still a Case in Point for "Legitimacy"?}

Looking back, what have we learned in terms of identifying starting points for a critical engagement with highly specialized regimes of transnational private regulatory governance? As noted before, much of the work done by lawyers in this global governance realm has either called for a public interest defense or singled out "legitimacy" as a potentially effective lever to scrutinize the legal nature of these transnational regulatory structures. But it is here that the complexity of the global governance context in relation to any encompassing concept of legitimacy has become more visible. In the transnational regulatory context, the pursuit of legitimacy depends on a comprehensive assessment of the different dimensions of this idea which lie beyond otherwise routinely assumed linkages between legality and its grounding in, say, democratic legitimacy. ${ }^{119}$ Not only has law become disembedded, but law's approaches to address its perennial legitimacy concerns ${ }^{120}$ have also lost a lot of their footing. ${ }^{121}$ Legitimacy concerns for the law today are inextricably caught up in law's existential efforts to redefine and to ascertain its role in societal governance altogether. As such, legitimacy in law and of law has become a laboratory for a multi- and interdisciplinary engagement with law's relation to and its place in society. ${ }^{122}$ Following the differentiation of modern world society, legitimacy concerns

\footnotetext{
${ }^{119}$ C. Schmitt, The Crisis of Parliamentary Democracy (Ellen Kennedy transl. [1926]) (MIT Press, 1988).

${ }^{120}$ An illustration of this continues to be the debate between H.L.A. Hart and L. Fuller. See Herbert Lionel Adolphus Hart, Positivism and the Separation of Law and Morals, 71 HARV. L. REV. 593 (1957/8), and Lon L. Fuller, Positivism and Fidelity to Law - A Reply to Professor Hart, 71 HARV. L. REV. 630 (1957/8). See the essays concerning this debate in THE HART-Fuller DeBATE IN THE TwEnTY-FiRST CEnTURY (Peter Cane ed., 2010).

${ }^{121}$ For an elaboration, see P. Zumbansen, 'Lochner Disembedded: The Anxieties of Law in a Global Context', (2013) 20 Indiana Journal of Global Legal Studies 29-69 [http://ssrn.com/abstract=2174017].

${ }^{122}$ One of the best studies outlining this context is by E. Darian-Smith, Laws and Societies in Global Contexts. Contemporary Approaches (Cambridge University Press, 2013).
} 
for law arise and are being addressed within highly sectionalized and specialized areas of regulatory governance, that is to say, they arise in a context that puts enormous pressure on any attempt to submit this constellation to an overarching theory of politics, or justice. ${ }^{123}$ But, at the same time, one can discern a distinct and pressing concern with this move away from an embedded system of law to a "global", decentralized regulatory governance framework. This concern is fuelled, partly, by anxieties over a possibly empty place of politics in the evolving global governance landscape. ${ }^{124}$ Albeit, neither the concept of politics itself nor the institutional or procedural framework in which we would have to re-situate politics today are evident. ${ }^{125}$ This leaves lawyers, in particular, as they set out to redraw the map of law's legitimacy in a global context from the perspective of a proliferating transnational private regulatory governance framework, in a considerable dilemma. Faced with a multitude of overlapping, fast-evolving private regulatory governance regimes in areas ranging from financial ${ }^{126}$ to environmental ${ }^{127}$ regulation, investment law ${ }^{128}$ or commercial transfers ${ }^{129}$, lawyers must continue to both expand their expertise with regard to specialized, technical transactional areas and appreciate the

${ }^{123}$ N. Luhmann, 'Globalization or World Society: How to Conceive of Modern Society?', (1997) 7 Int'l Rev. Sociol. 67-79; G. Teubner, 'The King's Many Bodies: The Self-Deconstruction of Law's Hierarchy', (1997) 31 Law \& Society Review 763-787.

${ }^{124}$ K. W. Abbott/D. Snidal, 'Hard and Soft Law in International Governance', (2000) 54 International Organization 421-456; P. Zumbansen, 'Comparative, Global and Transnational Constitutionalism: The Emergence of a Transnational Constitutional Pluralist Order', (2012) 1 Global Constitutionalism 16-51.

${ }^{125}$ For an insightful scrutiny, see GUNTHER TEUBNER, CONSTITUTIONAL FRAGMENTS. SOCIETAL CONSTITUTIONALISM AND GLOBALIZATION (2012); see the comprehensive engagement with this work by KarlHeinz Ladeur, The evolution of the law and the possibility of a "global law" extending beyond the sphere of the state - simultaneously, a critique of the "self-constitutionalisation" thesis", ANCILLA IURIS (2012), available at: http://www.anci.ch/_media/beitrag/ancilla2012_220_ladeur.pdf (last accessed: 1 December 2012).

${ }^{126}$ See, Katharina Pistor, Towards a Legal Theory of Finance, COLUMBIA PUBLIC LAw RESEARCH PAPER NO. $12-$ 323 (2012), available at: http://ssrn.com/abstract=2178000; John Biggins, “Targeted Touchdown” and "Partial Liftoff": Post-Crisis Dispute Resolution in the OTC Derivatives Markets and the Challenge for ISDA, 13 GERMAN LAW Journal (2012), in this issue; Colin Scott, Beyond Taxonomies of Private Authority in Transnational Regulation, 13 GERMAN LAW JOURNAL (2012).

${ }^{127}$ Kirsten Mikadze, Public Participation in Global Environmental Governance and the Equator Principles: Potentials and Pitfalls, 13(12) Germ. L. J. (2012); J. Conley/C. Williams, 'Global Banks as Global Sustainability Regulators? The Equator Principles', (2011) 33 Law \& Policy forthcoming; Andrian Lozinski, The Equator Principles: Evaluating the Exposure of Commercial Lenders to Socio-Environmental Risk, 13(12) GERM. L. J. (2012); Gail Henderson, Institutional Investors as Transnational Environmental Regulators? The Limits of Responsible Investing as Environmental Regulation, 13(12) GERM. L. J. (2012).

${ }^{128}$ Douglas Sarro, Do Lenders Make Effective Regulators? An assessment of the Equator Principles on project finance, 13(12) GERM. L. J. (2012).

${ }^{129}$ Agnieszka Janczuk-Gorywoda, Public-Private Hybrid Governance for Electronic Payments in the European Union, 13(12) GERM. L. J. (2012). 
relevance of non-legal ordering and regulatory concepts which underlie and inform many of the emerging governance regimes. ${ }^{130}$

Transnational private regulatory governance as a field of research sits squarely in the discursive

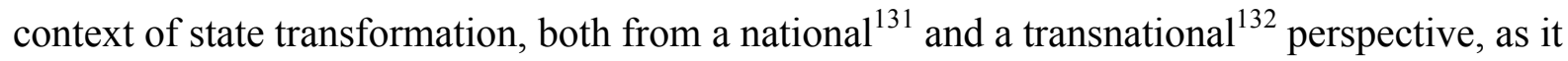
addresses a fundamental de-centering of both rule creation, dissemination and adjudication processes and of the conceptual frameworks with which we have learned to measure the legality and legitimacy of these processes. ${ }^{133}$ This unsettling of the state-law nexus has come under broad scrutiny, a development that finds expression in numerous iterations under titles such as Law and Globalization $^{134}$, Global Legal Pluralism ${ }^{135}$ as well as Transnational Law. ${ }^{136}$ Notwithstanding their analytical and conceptualizing function, such frameworks are drawn upon in an attempt to address the contested nature, form and scope of law 'in a global context', that is a context that has greatly amplified law's normative and pluralist challenges. The multifaceted phenomenon of transnational private regulatory governance can here serve as a powerful illustration of how the analytical interest in the maintenance of the state-law nexus must move away from law itself and towards an engagement with the Actors, Norms and Processes [ANP] in which law appears to be

${ }^{130}$ Tony Porter, Transnational Private Regulation and the Changing Media of Rules, 13 GERMAN LAW JOURNAL (2012), in this issue; Matthew Chan, Psychological Actors - Behavioral Analysis of Equator Principles Adoption, 13(12) GERM. L. J. (2012), in this issue, available at: (last accessed: 17 February 2014).

${ }^{131}$ Stephan Leibfried \& Michael ZÜRn Eds., Transformations of The StATe? (2005); Peer Zumbansen, Law after the Welfare State: Formalism, Functionalism and the Ironic Turn of Reflexive Law, 56 AMER. J. OF COMP. L. 769-805 (2008), available at: http://ssrn.com/abstract=1128144, reprinted in NILS JANSEN \& RALF MICHAELS EDS., BEyOnd THE StATE - RETHINKING PRIVATE LAW 349-386 (2008).

${ }^{132}$ Gregory Shaffer, Transnational Legal Process and State Change, 37 LAW \& SoCIAL INQUIRY 229 (2011)

${ }^{133}$ J. Black, 'Decentering Regulation: The Role of Regulation and Self-Regulation in a 'Post-Regulatory' World', (2001) 54 Current Legal Problems 103-146.

${ }^{134}$ P. S. Berman, 'From International Law to Law and Globalization', (2005) 43 Columbia Journal of Transnational Law 485-556 (2005); U. Sieber, 'Rechtliche Ordnung in einer Globalen Welt', (2010) 41 Rechtstheorie 151-198 (2010).

${ }^{135}$ R. Michaels, 'Global Legal Pluralism', (2009) Annual Review of Law \& Social Science, vol. 5 (also Duke Public Law \& Legal Theory Research Paper No. 259)

http://papers.ssrn.com/sol3/papers.cfm?abstract_id=1430395http://papers.ssrn.com/sol3/papers.cfm?abstract id=143 0395 (last accessed: 1 December 2012); P. S. Berman, 'Global Legal Pluralism', (2007) 80 Southern California Law Review 1155-1237 (2007).

${ }^{136}$ P. C. Jessup, Transnational Law (Yale University Press, 1956); C. M. Schmitthoff, 'Nature and Evolution of the Transnational Law of Commercial Transactions', in N. Horn and C. Schmitthoff (eds), The Transnational Law of International Commercial Transactions 1982), 19-31; C. Tietje/K. Nowrot, Laying Conceptual Ghosts of the Past to rest: The Rise of Philip C. Jessup's 'Transnational Law' in the Regulatory Governance of the International Economic System, Essays in Transnational Law 50/2006). 
caught up. ${ }^{137}$ These three categories, then, assume the role of translation devices through which governance discourses as they have unfolded in the nation-state context can be put in relation to governance discourses on the transnational level. Instead of transposing nation-state originating concepts such as the rule of law, judicial review or separation of powers onto the global scale, a the use of ANP might help to highlight the parallels but also the distinct differences and incompatibilities between known regulatory concepts and those which seem to be emerging on the transnational level. From the perspective of an ANP approach to the study of "law and globalization", transnational private regulatory governance offers numerous crucial insights into the newly forming relations between law and society in a global context. Part of the reason for the lively scholarly interest in these processes can be found in the way, that these transnational regulatory regimes appear to enunciate and embody all these transformations which are associated today with the nation state in a globalized setting. The state's alleged retreat, its loss of regulatory ability, reach and implementation are frequently invoked as mere mirror effects of a widely encompassing privatization and autonomization of regulatory regimes, associated with a neo-liberal transformation of public governance. ${ }^{138}$ It is against that background, that a legal theoretical engagement with transnational regulatory governance becomes crucial. Such a legal theory must adopt a perspective of methodological transnationalism in view of the differentiation of regulatory systems across spatial boundaries in an attempt to more effectively engage with the contested aspects of legality, accountability and legitimacy.

\footnotetext{
${ }^{137}$ P. Zumbansen, 'Lochner Disembedded: The ANXIETIES of LAW In A Global ConteXT', (2013) 20 INDIANA JOURNAL OF GLOBAL LEGAL STUDIES 29-69 [HTTP://SSRN.COM/ABSTRACT=2174017]; P. Zumbansen, 'What lies Before, Behind and Beneath a Case? Five Minutes of Transnational Lawyering and the Consequences for Legal Education', in S. Van Praagh and H. Dedek (eds), Stateless Law: Evolving Boundaries of a Discipline (Ashgate, 2014), forthcoming (http://ssrn.com/abstract=2370428).

${ }^{138}$ A. Aman Jr., 'Law, Markets and Democracy: A Role for Law in the Neo-Liberal State', (2007) 51 New York Law School Review 801-815; Levi-Faur, supra, note 7.
} 